\title{
Eric Hoppenot
}

\section{Poetic Language and Prophetic Language in Levinas's Works}

"Kafka said to Janouch that "the task of the poet is a prophetic task [. . .]" (Blanchot 1982, 73), ${ }^{1}$ determining in the same conversation that the Jewish people live with the voices of Scripture, that these are by no means relegated to the past, and that, on the contrary, they are in the present.

The manuscript of Emmanuel Levinas's "The Servant and Her Master," held in the Maurice Blanchot archive, contains several additions to the published article Levinas dedicated to Maurice Blanchot's narrative Awaiting Oblivion (1963). A relatively lengthy addition was to constitute a footnote in the version first published in the celebrated volume of Critique from June, $1966,{ }^{2}$ a special issue comprising the first volume of collected articles dedicated to Blanchot, and was subsequently included in Levinas's volume On Maurice Blanchot (1975). The footnote reads:

No ethical element comes into play in Blanchot's work so as to constitute this modality. It
is not owing to its impoverished nature, nor to persecution or contempt, that it acquires
the privilege of disappearing from the horizon, of transcending it, and then responding
from the depths of its absence only to the call of the best. And yet every now and then,
transcendence in Blanchot consists of the very uncertainty of presence, "as if she were
only present so as to prevent herself from speaking. Then came the moments when, the
thread of their relationship having been broken, she recovered her calm reality. It was at
those moments that he saw better in how extraordinary a state of weakness she was, one
from which she drew that authority which sometimes made her speak" (pp. 25-6). We
said earlier that the word poetry referred to the disruption of immanence to which lan-
guage is condemned in becoming its own prisoner. There is no question of considering
this disruption as a purely aesthetic event. But the word poetry does not after all name a
species whose genus is referred to by the word art. Inseparable from speech (le verbe), it
overflows with prophetic meanings.
(Levinas 1989, 158-159)

1 The French translation of Gustav Janouch's Gespräche mit Kafka uses the word "writer" and not "poet" (see Janouch 1998, 231).

2 Critique 229 (1966), special issue devoted to Maurice Blanchot.

3 This footnote refers to the sentence: "Such is the scintillating modality of transcendence, of what truly comes to pass.” (Levinas 1989, 156)

Translation: Translated, from the French, by Ashraf Noor 
I thought that I would find other instances in Levinas's work reaffirming this marginal comment that poetry "overflows with prophetic meanings," a statement that one intuits immediately as sounding like a Levinasian expression, so indubitably familiar are we with the recurrence of the verb "to overflow" in Levinas's vocabulary. There is, however, in fact nothing that resonates with this marginal expression. Moreover, the only evocation of the prophetic in Levinas's Sur Maurice Blanchot is found in this sole note. Is it possible, though, to articulate something between the poetic and the prophetic in the Levinasian space? Or, further, does the poetic only overflow with "prophetic meanings" in the unique work of Blanchot, as the hapax that we have just pointed out seems to underline?

\section{Song}

In the Carnets de captivité, Levinas associates poetry first of all with musicality. "Poetry is therefore like a rhythm. [...] Poetry is things set to music" (Levinas 2009, 100). Even more decisively, four pages further, we find this statement: "Rhyme and its technique are neither the obstacle nor the guide of thought. They are the very condition of art." This is a point of view that assumes a relatively conventional, indeed outdated, representation of poetry. No contemporary poet would seriously share this statement. What seems to me entirely worthy of interest in this movement giving birth to thought that begins to become writing is to observe the manner in which the poetic semination, in one of the philosophical potentialities as yet unthought by Levinas, becomes the binding encounter. In a word, and to paraphrase one of Heidegger's titles, poetry is on the way to philosophy, not because it claims in any way to elevate itself to philosophy but because it bears within itself a surge of thought, at least of language. Thus, after having explicated the possibility for poetry to detach itself by its musicality from all objective meaning, Levinas writes "the philosophical concept is also able to de-materialize itself in such a way [as poetry] and become like art itself profound knowledge" (Levinas 2009, 115). Shortly after, Levinas asks himself whether, finally, metaphysics and existence itself are not art.

The first proximity between poetry and prophecy is, before anything else, even before the word, the Said, the offering of song. Both discourses participate in song, something preceding the event of meaning, the voice itself, its intonation, its melody, its rhythm. This is the case from Levinas's first texts, from Existence and Existents, where he seeks to describe what he calls exoticism, a concept that is nothing if not reminiscent of Baudelaire, whom he cites 
frequently and with whom Totality and Infinity concludes. Exoticism is that which is liable to tear us from the world, and this is how Levinas refers to the arts, particularly to music and to the musicality of poetry. The attraction, the power of art, that which Blanchot calls "the fascination," consists of extricating oneself from perception in order to give way to sensation. It is this confusing of sensation in the image of the object and not in the object itself, which Levinas defines as aesthetics.

In "Reality and Its Shadow," however, exoticism takes a completely different turn, and the exotic musicality of poetry, which hitherto harboured fecundity, moves into magic, a relatively rare word in Levinas's vocabulary, or into sorcery: "Rhythm represents a unique situation where we cannot speak of consent, assumption, initiative, or freedom, because the subject is caught up and carried away by it [. . . ] for in rhythm there is no longer anything of oneself, but rather a passage from oneself to anonymity [thus to Blanchot's universe! -EH]. This is the sorcery or the incantation of poetry and music." (Levinas 1989, 132-133) The rhythm of song or poetry relegates the subject to a posture that is ecstatic posture, if I may force the word a little, but in a way that condemns it to passivity or fastens it to the present of contemplation. In this essential article, there is no word severe enough for Levinas to characterize the errance into which art, and not only the image, leads us, even if this latter is endowed with a power to fascinate that is stronger than poetry. If poetry, in contrast to the prophetic word, entrances, this is because it maintains a relation of itself to itself and freezes time in a present that does not pass. This is the very definition of fascination: absorbed in poetic literature, the reader, in strict terms, "does not see time passing." It is pleasure, certainly, but pleasure that entrances. Art is the time that freezes things in an eternal present. Prophetic time is completely different. The prophetic word inaugurates a disturbance such that the very concept of the future becomes practically aporetic: an impossible future or impossibility as future. To announce an impossible future is to offer a word that escapes the chain of effects and of causes, the logical course of time, as a consequence of which the prophetic offering announces itself in a language that can be not received by the people to whom it is addressed. This is attested, for example, in the reticence manifested by the Hebrews who at first refuse to leave Egypt. The impossible future founded in the prophetic word implies a word that abstracts entirely from what is, without a hold on the past. Thus for Blanchot: "But prophetic speech announces an impossible future, or makes the future it announces, because it announces it, something impossible, a future one would not know how to live and that must upset aIl the sure givens of existence. When speech becomes prophetic, it is not the future that is given, it is the present that is taken away, 
and with it any possibility of a firm, stable, lasting presence.” (Blanchot 2003, 79)

If the present is as if "withdrawn," this is because prophetic language sets all categories of representation ablaze. The advent of the prophetic address explodes the very possibility of the present, substituting for the awaited present a word, which in some way uproots and tears away the pleasure of the instant, of the fascination of the poetic song. Prophecy comes to destroy the present, imposing a configuration in which the present already contains the future. Awaiting the Messiah, Levinas writes, "marks the very duration of time" (Levinas 1990, 26).

In Totality and Infinity, the critical tones announced in "Reality and Its Shadow" are nearby: "Every work of art is painting and statuary, immobilized in the instant or in its periodic return. Poetry substitutes a rhythm for the feminine life. Beauty becomes a form covering over indifferent matter, and not harboring mystery." (Levinas 1979, 263) In sorcery, one will recognize the song of the Sirens that Ulysses, this antinomian figure to Abraham, has to confront.

But in analyzing Blanchot's writing, Levinas defends the argument according to which the poetic transformation to which the writer makes language submit would have the faculty of overcoming the rustling of the world. Would the song that overwhelms the literary space offer a hypostatic modality to the subject or is it reduced to an illusion, as the motif of bewitchment would suggest? Levinas will emphasize at various junctures, outside the restricted context of his commentaries on Blanchot, the necessity of thinking the poetic event as the possibility offered to language of extracting itself from immanence.

At least two bodies of works, those of Solomon and those of David, ${ }^{4}$ realize a discursive coalescence between the poetic and the prophetic. In Du sacré au saint, Levinas characterizes the psalms as poetry, and in the part of Difficult Freedom devoted to "Messianic Commentaries" one reads: "'King David' is distinguished here from the Messiah. He is the author of the Psalms, where poetry merges with prayer and prayer spills over into poetry. The word has meaning from the moment adoration is produced in this world, where a finite being stands before something which goes beyond him, but where this presence before the Most High becomes the psalm's exaltation" (Levinas 1990, 84). (One can rightfully make a distinction here and hear that the Psalms are not prophetic narrations.) It seems to me that it is precisely at this point of encounter that poetry can overflow with "prophetic meanings," this point at which the

4 See Levinas, In the Time of the Nations (1994, pages 23 and 68, respectively). 
discovery of the divine enjoins the necessity of an alternative discursive modality where the poetic song would not, like that of the Sirens, intend to entrance the reader but where the speaking poet would be affected, perhaps disrupted by a language that is not wholly his own. Does this mean to say that poetry would not associate with the prophetic except under the condition that it proclaim praise of the infinite? Would this imply that the coalescence I evoked cannot take place except at the heart of religious, mystical poetry? If we are to believe Levinas's acerbic commentaries on Claudel's work, the religious character of poetry by no means implies this advent of the prophetic as hospitality. And even if he concedes to Claudel his admiration for the work Les Patriarches, attentive eyes will see in this once again the reiteration of poetry defined as "sorcery."

One finds, however, from time to time approaches to poetry that are less negative, and this is why, to my mind, it is very difficult to determine the logic of Levinas's discourse on art. Even if the note in Otherwise than Being, which I read as an extended echo of "Reality and Its Shadow," rings clearly as a rejection of art:

The immemorial past is intolerable for thought. Thus there is an exigency to stop: ananké
stenai. The movement beyond being becomes ontology and theology. And thus there is
also an idolatry of the beautiful. In its indiscrete exposition and in its stoppage in a
statue, in its plasticity, a work of art substitutes itself for God. [. . .] By an irresistible sub-
reption, the incomparable, the diachronic, the non-contemporaneous, through the effect
of a deceitful and marvelous schematism, is "imitated" by art, which is iconography. The
movement beyond being is fixed in beauty. Theology and art "retain" the immemorial
past.
(Levinas 1998b, 199)

But let us also be attentive to what can be generous in the description of the poetic act, for example in Humanism of the Other: "Language as expression is above all the creative language of poetry. So art is not the lovely madness of man who takes it into his head to make beauty" (Levinas 2003, 17). And describing the poetry of Agnon, which he considers as "pure poetry," he announces: "Poetry signifies poetically the resurrection that sustains it: not in the fable it sings but in its very singing" (Levinas 1996, 12). The essence of poetry, contrary to the prophetic message, uncovers, in a way, its essence through the decision to sing even before the word manifests itself as meaning. In poetry, according to Levinas, the word goes first not towards its meaning but rather towards the materiality of the sound. It seems to me that, in this regard, one could also examine the question of the cry such as it is found in certain poets and the cry to which Levinas accords a role in evoking the "ethical revolt" that "begins in prophecy" (Levinas 1998a, 77). This is, of course, the "voice that cries out in the wilderness," without speaking of the written cry that he evokes 
when proceeding from what Blanchot wrote about the graffiti posted on the walls of Paris in May 1968, where it was also a matter of an expression so often poetic. The cry as a song that derails, as an excess of the voice, would also need to be interrogated in this articulation of poetic/prophetic word.

\section{Prophetic Speech, between Ruah and Davar}

The prophet, in a different sense than the poet, is an inspired being. To be inspired consists in thinking that the world has been created, and its creation continued, by the word. Levinas evokes the "disproportionate voice of a God addressing human beings in the prophetic or poetic tongue" (Levinas 1994, 112). God has placed in the prophet the ruah that imparts its energy to him. Claude Tresmontant defines ruah as "the supernatural dimension proper to Biblical revelation" (Tresmontant 1977, 108). According to the Biblical tradition, however, everyone is capable of being a prophet. For Levinas, the prophetic is even one of the modes of being human. Every person is potentially a prophet, as is announced in a verse in Numbers 11:29: "Would that all Yahwe's people be prophets!” It is due to the ruah that the human escapes abandonment, that he discovers he is not alone. It is equally through inspiration that the relation to God is established as dialogue, God's ruah speaking with that of humans. André Neher wrote that the ruah of God is "pathetic," a characterization that can be affected by all the anthropo-pathic dangers, but that describes very precisely the action of the spoken word. God addresses humans with his pathos, manifesting in this way his attention to what is human. It is through pathos that he can grasp the prophet and demand that he not stray from his mission. The pathos of poetry, however, evidently shelters something very different.

Nevertheless, the prophet is not only he who responds to the injunction, to the divine ruah, but he is also the one who bears the spoken word, the davar. Ruah and davar cannot be disassociated. If the davar is an expression of violence, it is also the manifestation of the pleasure of the spoken word, as is testified by the well-known passage in Ezekiel 3:1-3 where Ezekiel delights in eating the book that tastes of honey. In taking up Levinas's comment on Blanchot once again, while inverting it, one could say that the prophetic word overflows with poetic meanings. Without a doubt, poetry is necessary for the prophetic word. The divine language is a word that nourishes, but could one dare to suggest that the poetic word nourishes the effusion for the divine in the same way that prayer does? 
In Levinas's eyes, however, prophecy does not hide the truth of existence; it reveals, but only exercises its power under the singular condition that it makes itself, according to the Law and as Benny Lévy said in a seminar on the philosophy of Levinas, the injunction of existence. It is fundamentally of little importance if the prophet has a particular relation to time, at least in its predictive or oracular dimension (cf. particularly Levinas1998b, 96). Where it seems to me that the prophetic never ceases to resonate in his work is in this verse of Amos that he cites abundantly like a refrain inherent to his writing: "The Lord God has spoken; who can but prophesy?” (Amos 3:8). Levinas will say with respect to Amos that his prophetic inspiration manifests itself through his utterance.

At least once in his works, in addition to our initial example of the note on Blanchot, Levinas will commit himself to recognizing not only a proximity but a quasi-identity between the prophetic and the poetic. In a passage from In the Time of the Nations, we read: "Completion and authority, the disproportionate voice of a God addressing human beings in the prophetic or poetic tongue. This is an ascent within words, be they the most recent ones, to I know not what antiquity that is already to be translated, already to be deciphered" (Levinas 1996, 112).

The divine word is a shock, it harasses the subject in his entrenchment let us recall Jonah -and does not cease to summon him. If Blanchot maintains essentially the dynamic of davar and its hyperbolic character, it is because the divine word is intrinsically action. It judges, it condemns, it saves, it heals, it commands. In the davar, the prophet is not relieved of his language in order to be nothing other than the receptacle and the utterer of the divine word, but he enters into a veritable dialogical configuration with God.

In the manner of God, who creates the world through language, the nabi, because he is the divine spokesman par excellence, creates the conditions of a dialogical space and temporality where everything works in the verticality of exchange. The prophet is not only he who listens and transmits; he is not a simple receptacle, for the nabi possesses the extraordinary power of appealing to God. In other words, he is both the locus of the appeal and that of the initial response. The prophetic utterance bears the word to the highest point of its engagement, to the extent that it inaugurates a face to face between the people and the word from Outside. With regard to this word that is absolutely other it is necessary to be bound by the responsibility of a decision involving his future and the future of coming generations. How does the resonance of this dialogue manifest itself? According to Levinas: "Prophetism could be the name of this reversal in which the perception of order coincides with the fact that he who obeys it also signifies it. Prophetism would thus be the very psyche of the soul, 
the Other within the Same, where the within signifies the waking up of the Same by the Other" (Levinas 2000, 200). And once more, still describing the verse of Amos, Levinas will add: "Prophetism as pure witnessing, pure, because prior to all disclosure; this is a subjection to an order prior to the understanding of the order." (Levinas 1998a, 76) This is a statement that cannot but remind us of the "we shall do and we shall hear" of the scene in Sinai.

This is why the prophet is always confronted with the trial of the reception of his own speech, of his power of persuasion. The action of the people is the response to the prophetic davar. Poetry is clearly deprived of this pragmatic and injunctive dimension, even if, as Levinas will read and will say with respect to Celan's poetry, poetry is an outstretched hand, or to say this differently, an offering addressed to the other; yet it is also, for Celan, writing in a bottle launched into the sea, its destination fragile and uncertain.

In the same way, prophetic writing is the only one for which a date is set, for it bears its own end within itself (prophetic time is limited). It sets itself forth simultaneously for the present and for the messianic age. Poetic time, the time of art, the time that always remains that of Narcissus, is completely different.

\section{Concluding Remarks}

To conclude these too rapid remarks, let us examine briefly what distinguishes Levinas's prophetic thought from that of Blanchot. If Blanchot emphasizes the aspect of time in his interpretation of prophecy, Levinas, loyal in this to the rabbinical tradition, prefers the sage to the prophet but above all invites us to think the human condition as prophecy, this being a condition of ethics.

If one agrees with Levinas's thought, it appears that prophecy is not only something that is possible for man but also, and further, that the prophetic is a moment of the human condition that signifies responsibility for the Other. The prophet would not be merely a voice that professes but one that bears the responsibility for his word and in the responsibility for his Saying manifests that for the Other. The prophet's language responds to, and is accountable for, "the epiphany of the face of the Other." One can be sensitive to the distinction Levinas makes between the prophet and the witness, who is not subjected to the order for he anticipates it and responds "Here I am!” before any request. Finally, one understands why in Levinas's thought and in Jewish thought in general the prophet is not glorified - and this holds all the more for the poet! Jewish thought will always prefer the sage to the prophet. Does 
that mean, as Levinas considers, that Rabbi Akiba will always take precedence over Moses?

If, however, a link could once be established between the prophetic according to Levinas and that described by Blanchot, one would find a trace of this, and by no means a faint one, in The Writing of the Disaster, where it is Levinas's very philosophy that Blanchot characterizes as prophecy. ${ }^{5}$ According to this, Levinas's Jewish philosophy is prophetic inasmuch as it has yet to be thought. Why? It is because "it bears responsibility for the future" and because it has to "care for hope." 6 In other words, the Jewish word is in some way still to come, it is at play in the attentive study of the oral tradition, which pursues without cease the word inherited from the prophets. ${ }^{7}$ It is in addressing his questions to the text that the Jew responds to the call.

\section{Bibliography}

Banon, David. Entrelacs: La lettre et le sens dans l'exégèse juive. Paris: Editions du Cerf, 2008. Blanchot, Maurice. The Space of Literature. Trans. Ann Smock. Lincoln: University of Nebraska Press, 1982.

Blanchot, Maurice. The Writing of the Disaster. Trans. Ann Smock. Lincoln: University of Nebraska Press, 1986.

Blanchot, Maurice. "Prophetic speech", in The Book to Come. Trans. Charlotte Mandell. California: Stanford University Press, 2003. 79-85.

Blanchot, Maurice. Ecrits politiques, 1953-1993. Paris: Gallimard, 2008.

Draï, Raphaël. La communication prophétique. Volume I. Le Dieu caché et sa revelation. Paris: Fayard, 1990.

Janouch, Gustav. Conversations avec Kafka. Trans. Bernard Lortholary. Paris: Maurice Nadeau, 1998.

Levinas, Emmanuel. Totality and Infinity: An Essay on Exteriority. Trans. Alfonso Lingis. The Hague: Martinus Nijhoff, 1979.

Levinas, Emmanuel. "Reality and Its Shadow." Trans. Alphonso Lingis. The Levinas Reader. Ed. Seán Hand. Oxford: Blackwell, 1989. 129-143.

5 See Blanchot (1986, note 148). This footnote is sufficiently important to be taken up once more in the form of a quote in the article "N'oubliez pas" (1983), in Ecrits politiques 1953-1993 (Blanchot 2008, 40).

6 According to Raphaël Draï $(1990,135)$, there could not be prophecy without hope, even if this is not dominant.

7 One can read profitably, in David Banon's Entrelacs: La lettre et le sens dans l'exégèse juive, the chapters "Du prophète au rabbi ou de la voix à la lettre: une lecture d'adultes" (Banon 2008, 19-46), as well as the chapter devoted to André Neher, "André Néher et la Bible. Approche nouvelle et langage neuf" (Banon 2008, 143-157). 
Levinas, Emmanuel. "The Servant and Her Master." Trans. Michael Holland. The Levinas

Reader. Ed. Seán Hand. Oxford: Blackwell, 1989. 150-159.

Levinas, Emmanuel. Difficult Freedom. Trans. Seán Hand. Baltimore: Johns Hopkins University Press, 1990.

Levinas, Emmanuel. In the Time of the Nations. Trans. Michael B. Smith. London: The Athlone Press, 1994.

Levinas, Emmanuel. Proper Names. Trans. Michael B. Smith. London: The Athlone Press, 1996. Levinas, Emmanuel. Of God Who Comes to Mind. Trans. Bettina Bergo. Stanford: Stanford University Press, 1998a.

Levinas, Emmanuel. Otherwise Than Being or Beyond Essence. Trans. Alphonso Lingis. Pittsburgh: Duquesne University Press, 1998b.

Levinas, Emmanuel. God, Death, and Time. Trans. Bettina Bergo. Stanford: Stanford University Press, 2000.

Levinas, Emmanuel. Humanism of the Other. Trans. Nidra Poller. Chicago: University of Illinois Press, 2003.

Levinas, Emmanuel. CEuvres complètes. Volume I. Carnets de captivité et autres inédits. Eds. Rodolphe Calin and Catherine Chalier. Paris: Grasset/IMEC, 2009.

Tresmontant, Claude. Le prophétisme hébreu. Paris:François Xavier de Guibert, 1977. 